\title{
Conjugating effects of symbionts and environmental factors on gene expression in deep-sea hydrothermal vent mussels
}

Isabelle Boutet ${ }^{1,2^{*}}$, Raymond Ripp ${ }^{3}$, Odile Lecompte ${ }^{3}$, Carole Dossat ${ }^{4}$, Erwan Corre ${ }^{5}$, Arnaud Tanguy ${ }^{1,2}$ and François H Lallier ${ }^{1,2}$

\begin{abstract}
Background: The deep-sea hydrothermal vent mussel Bathymodiolus azoricus harbors thiotrophic and methanotrophic symbiotic bacteria in its gills. While the symbiotic relationship between this hydrothermal mussel and these chemoautotrophic bacteria has been described, the molecular processes involved in the cross-talking between symbionts and host, in the maintenance of the symbiois, in the influence of environmental parameters on gene expression, and in transcriptome variation across individuals remain poorly understood. In an attempt to understand how, and to what extent, this double symbiosis affects host gene expression, we used a transcriptomic approach to identify genes potentially regulated by symbiont characteristics, environmental conditions or both. This study was done on mussels from two contrasting populations.

Results: Subtractive libraries allowed the identification of about 1000 genes putatively regulated by symbiosis and/ or environmental factors. Microarray analysis showed that 120 genes (3.5\% of all genes) were differentially expressed between the Menez Gwen (MG) and Rainbow (Rb) vent fields. The total number of regulated genes in mussels harboring a high versus a low symbiont content did not differ significantly. With regard to the impact of symbiont content, only $1 \%$ of all genes were regulated by thiotrophic (SOX) and methanotrophic (MOX) bacteria content in MG mussels whereas $5.6 \%$ were regulated in mussels collected at Rb. MOX symbionts also impacted a higher proportion of genes than SOX in both vent fields. When host transcriptome expression was analyzed with respect to symbiont gene expression, it was related to symbiont quantity in each field.

Conclusions: Our study has produced a preliminary description of a transcriptomic response in a hydrothermal vent mussel host of both thiotrophic and methanotrophic symbiotic bacteria. This model can help to identify genes involved in the maintenance of symbiosis or regulated by environmental parameters. Our results provide evidence of symbiont effect on transcriptome regulation, with differences related to type of symbiont, even though the relative percentage of genes involved remains limited. Differences observed between the vent site indicate that environment strongly influences transcriptome regulation and impacts both activity and relative abundance of each symbiont. Among all these genes, those participating in recognition, the immune system, oxidative stress, and energy metabolism constitute new promising targets for extended studies on symbiosis and the effect of environmental parameters on the symbiotic relationships in B. azoricus.
\end{abstract}

Keywords: Bathymodiolus azoricus, symbiosis, gene expression, environment

\footnotetext{
* Correspondence: isaboutet77@gmail.com

${ }^{1}$ CNRS, UMR 7144, Adaptation et Diversité en Milieu Marin, Station

Biologique de Roscoff, 29682 Roscoff, France

Full list of author information is available at the end of the article
} 


\section{Background}

Symbiosis, defined as an interdependent relationship between two species, is an important driver of evolution, diversity, and increased plasticity in eukaryotes. The underlying biological processes of these associations were highlighted by recent analyses coupling genomic and evolutionary data [1] that showed that a part of biological adaptation and phenotypic novelty in a species is due to the acquisition of functional systems from other species in a mutualistic symbiosis. In the ultimate mutualistic association, the symbionts are located in host cells and are transmitted vertically through successive generations. This kind of association was at the root of mitochondria and chloroplast establishment in eukaryotes [2]. Similarly, associations between chemoautotrophic bacteria (thiotrophic and/or methanotrophic) and invertebrates are ubiquitously described in reducing marine ecosystems, such as mangrove mud, anoxic sediments, hydrothermal vents and cold seeps [3]. The symbiotic relationship between chemoautotrophic bacteria and invertebrates at deep-sea hydrothermal vents and cold seeps, as well as the parameters influencing the regulation and variations of mRNA expression across individuals, remains poorly understood at the transcriptome level, even though symbiotic organisms are the major component of biomass in these ecosystems. Different studies have focused on the process of symbiont acquisition and characterization of genes differentially regulated between organisms at different symbiotic states [4-10]. These transcriptomic approaches are based on sequence libraries and expression levels determined by real-time PCR that are mainly descriptive and therefore do not give information about the source of inter-individual gene expression variations. For example, are these variations due to the symbionts and/or environmental conditions? Moreover, these studies were mainly conducted on organisms under laboratory conditions to identify regulated genes and analyze their mRNA expression during the process of symbiont acquisition. In their work, Voolstra et al. [9] followed gene expression of larvae of the corals Acropora palmate and Montastraea faveolata after exposure to Symbiodinium algal strains that differed in their ability to establish symbiosis. They showed that the corals' transcriptomes remained almost unchanged during infection by competent symbionts, but were altered by symbionts that failed to establish symbiosis. The authors suggested that successful coral-algal symbiosis depended mainly on the symbionts' ability to enter the host in a stealth manner rather than by provoking a more active response from the coral host. Environmental factors, such as water temperature, had a major impact on the symbiotic relationship between coral and zooxanthellae by compromising the acceptance of the symbiont by the host during the acquisition step, and consequently, variations in gene expression of the host were observed [10]. These studies on symbiotic marine organisms provide evidence of the combined impact of symbionts and environmental factors on the mRNA expression of the host.

Hydrothermal vent mussels of the genus Bathymodiolus are distributed worldwide and often constitute a major component of the fauna inhabiting hydrothermal vents and cold seeps. The majority of hydrothermal and cold-seep organisms developed a single endosymbiosis, generally with sulfur-oxidizing (SOX) bacteria, though occasionally with methanotrophs (MOX). Vent and seep mussels harbor either a single endosymbiont strain, like B. thermophilus (SOX bacteria) or B. childressi (MOX bacteria) [11,12], or possess a double symbioses with both SOX and MOX bacteria, such as B. brooksii, $B$. heckerae, $B$. azoricus and B. puteoserpentis [13-16]. In contrast to gutless chemosymbiotic organisms in which the relationship with bacteria is obligatory, these mussels possess a functional digestive tract and isotope analyses have shown that they are able to obtain food by suspension feeding when necessary [17-19]. Moreover, Fisher and Childress [20] used both stable isotopes and histology to demonstrate that nutrient transfer from symbionts to mussel tissues results from the digestion of symbionts rather than nutrient translocation. The phylogeny of symbionts, especially those of both vent and seep mussels, has been thoroughly studied [15,21,22], as well as their (co-) localization in gill filaments [15,21-23]. Large genome- and transcriptome-scale analyses of hydrothermal vent host organisms have so far been done on symbiosis in tubeworms $[4,6]$ and heat adaptation [24-26]. No such studies have been done on symbiosis in tubeworms $[4,6]$ and heat adaptation [24-26]. No such studies have been done on Bathymodiolus symbiosis, despite its importance in hydrothermal vent ecosystems.

In the context of investigating chemoautotrophic symbiosis in vent taxa, we focused on the effect of both environmental factors and symbiont content on the established double symbiosis of vent mussels at the transcriptome level. Our approach combined the analysis of microarrays comprised of differentially expressed genes determined through suppressive subtraction hybridization ( $\mathrm{SSH}$ ) between hydrothermal vent mussels of $B$. azoricus inhabiting two different vent fields of the MidAtlantic Ridge (MAR) - different in depth, fluid temperature, $\mathrm{pH}$, and metal and methane concentrations. Our objective was to determine the effects of symbiont quantity and type, as well as environmental factors, on host gene expression at the transcriptome level in order to identify clusters of genes involved in the maintenance 
of symbiosis and/or in the response to environmental variations.

\section{Results}

Quantification of symbiont-specific gene expression

Real-time PCR measured significant differences $(P<$ 0.05) of both MOX and SOX quantities, and of symbiont-specific gene expression of ATP sulfurylase and monooxygenase A (pmoA), between the three vent fields: Menez Gwen (MG), Lucky Strike (LS) and Rainbow (Rb) (Table 1, Figure 1). Mussels collected at MG had a higher SOX content (273) and ATP sulfurylase expression $\left(1.1 \times 10^{-5}\right)$ compared to mussels collected at LS (167 and $8 \times 10^{-6}$, respectively) and at Rb (119 and $4.5 \times 10^{-6}$, respectively). Conversely, higher MOX content and pmoA expression were recorded in mussels collected at $\mathrm{Rb}$ (209 and 0.29 , respectively) compared to mussels from MG (26 and 0.12, respectively) and LS (16 and 0.07 , respectively).

\section{Sequencing of subtractive libraries}

The sequencing of the SSH libraries allowed the identification of 1058 unique, expressed genes distributed as follows (arrow points to subtracted library, and +/denotes relative level of $\mathrm{S}(\mathrm{OX})$ or $\mathrm{M}(\mathrm{OX})): \mathrm{S}_{+} \rightarrow \mathrm{M}+$ : 90; M+ $\rightarrow$ S+: 139; S+ $\rightarrow$ SM-: 82; SM- $\rightarrow$ S+: 126; S+ $\rightarrow \mathrm{M}-:$ 103; M- $\rightarrow$ S+: $110 ; \mathrm{M}+\rightarrow \mathrm{M}-:$ 108; M- $\rightarrow \mathrm{M}+:$ 134; M+ $\rightarrow$ SM-: 50; SM- $\rightarrow$ M+: 116. The distribution of annotated proteins into the GO classes is shown in

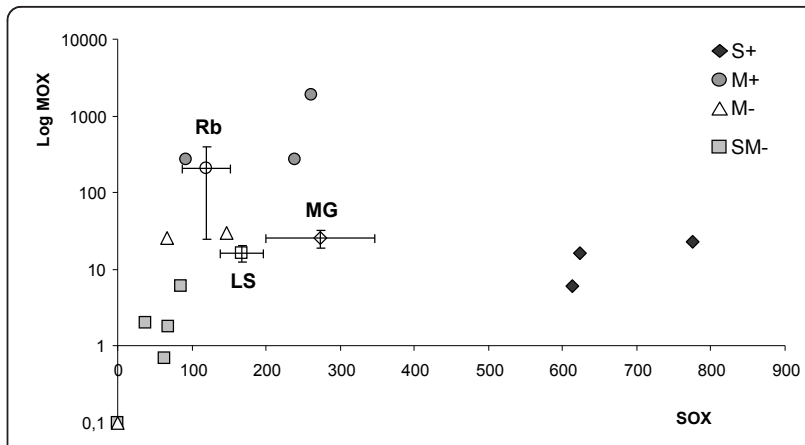

Figure 1 Quantification of symbionts in the mussels B. azoricus collected at the three vent fields Menez Gwen (MG, $n=25$ ), Lucky Strike (LS, $n=30$ ) and Rainbow (Rb, $n=25)$. Symbiont quantities in mussels used in subtractive library design are presented individually. S+, high SOX content ( $n=3$ ind from MG); SM-, low SOX and low MOX content $(n=5$ ind from MG, LS and $\mathrm{Rb}) ; \mathrm{M}-$, low MOX content ( $n=3$ ind from Rb); M+, high MOX content ( $n=3$ ind from Rb). Quantities of SOX and MOX are given as relative quantity in an arbitrary unit.

Figure 2. The sequences and their annotations are available online in a dedicated database using the following link: http://lbgi.igbmc.fr/Bathymodiolus/(Accession number: Genbank dbEST JK480449-JK483708).

\section{Microarray data analysis}

We focused our analysis on MG and Rb vent fields, the two most contrasted in terms of chemical environment and relative abundance of SOX/MOX, to highlight the

Table 1 Main concentrations in the Menez Gwen, Lucky Strike and Rainbow vent fluids, adapted from Douville et al. (2002), Charlou et al. (2000, 2002)

\begin{tabular}{|c|c|c|c|}
\hline & Menez Gwen $\left(37^{\circ} 50^{\prime} \mathrm{N}\right)$ & Lucky Strike $\left(37^{\circ} 17^{\prime} \mathrm{N}\right)$ & Rainbow $\left(36^{\circ} 14^{\prime} \mathrm{N}\right)$ \\
\hline \multicolumn{4}{|c|}{ Physical and chemical characteristics } \\
\hline Depth $(m)$ & 850 & 1700 & 2300 \\
\hline Temperature $\left({ }^{\circ} \mathrm{C}\right)$ & $265-284$ & $152-333$ & $360-365$ \\
\hline $\mathrm{pH}$ & $4.2-4.8$ & $3.5-4.9$ & $2.8-3.1$ \\
\hline $\mathrm{Fe}\left(\mathrm{mg} \mathrm{l}^{-1}\right)$ & $1.3-1.6$ & $1.7-48$ & 1339 \\
\hline $\operatorname{Mn}\left(\mathrm{mg} \mathrm{l}^{-1}\right)$ & $3.2-3.7$ & $4.2-24.7$ & 123 \\
\hline $\mathrm{Cu}\left(\mathrm{mg} \mathrm{l}^{-1}\right)$ & $40-180$ & $60-1650$ & 8900 \\
\hline $\mathrm{Zn}\left(\left.\mathrm{mg}\right|^{-1}\right)$ & $0.16-0.33$ & $0.33-3.79$ & 10.5 \\
\hline $\mathbf{C d}\left(\mathrm{mg} \mathrm{l}^{-1}\right)$ & $1.01-1.34$ & $2.02-8.85$ & 14.6 \\
\hline $\mathbf{P b}\left(\left.\mathrm{mg}\right|^{-1}\right)$ & $4.4-11.6$ & $7.2-26.9$ & 30.6 \\
\hline $\mathrm{H}_{2} \mathrm{~S}(\mathrm{mM})$ & $1.3-1.82$ & $0.6-3.3$ & $1-2.52$ \\
\hline $\mathrm{CH}_{4}(\mathrm{mM})$ & 1.7 & 0.52 & 2.5 \\
\hline \multicolumn{4}{|c|}{ Symbiont quantification } \\
\hline$n$ & 25 & 30 & 25 \\
\hline sox & $272.95 \pm 73.45$ & $166.71 \pm 28.92$ & $119.35 \pm 32.05$ \\
\hline MOX & $25.70 \pm 6.70$ & $16.38 \pm 4.07$ & $209.19 \pm 184.40$ \\
\hline ATP sulfurylase & $1.110^{-5} \pm 4.810^{-6}$ & $810^{-6} \pm 310^{-6}$ & $4.610^{-6} \pm 1.310^{-6}$ \\
\hline pmoA & $0.12 \pm 0.04$ & $0.07 \pm 0.02$ & $0.29 \pm 0.09$ \\
\hline
\end{tabular}

Relative quantities and activity of sulfide oxidizer bacteria (SOX and ATP sulfurylase) and methanotrophic bacteria (MOX and particulate methane monooxygenase $\mathrm{A}$ pmoA) were characterized in the present study and given in an arbitrary unit. 


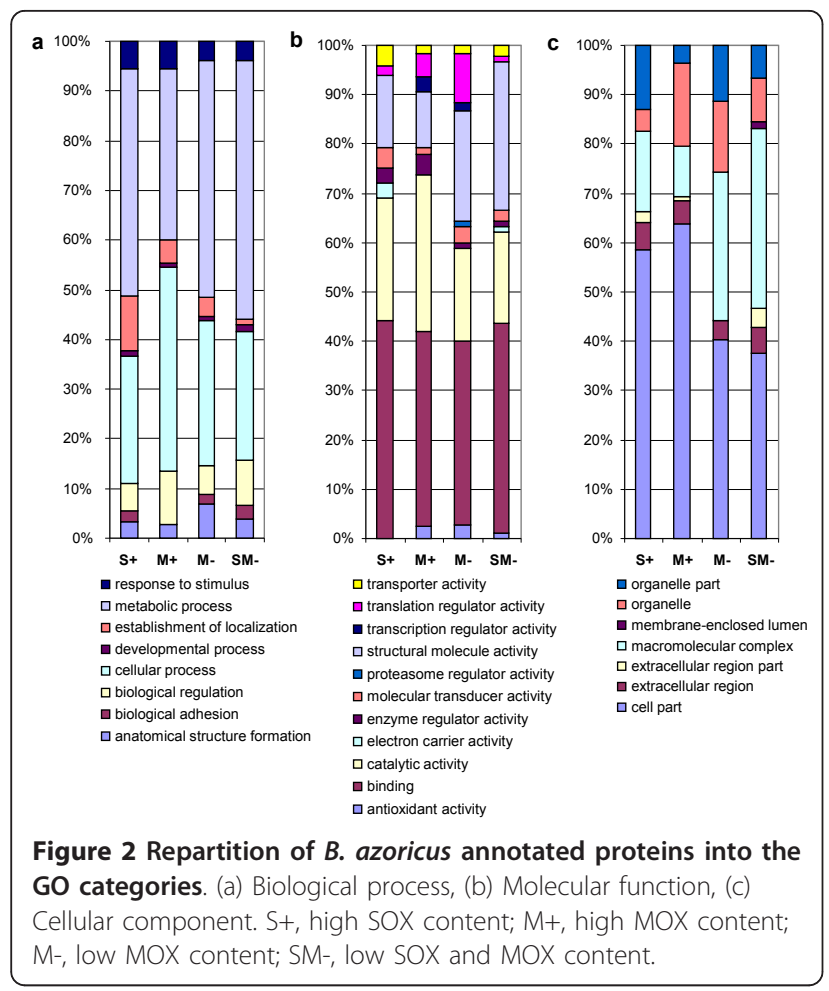

genes potentially regulated by symbionts and/or environmental parameters.

\section{Gene expression according to vent site characteristics}

To assess the influence of environmental parameters, the ratio of expression of each gene was calculated by dividing signal intensity of the gene for one given sample by the mean intensity of the gene in all samples in both populations. Our analyses showed that 120 genes (3.5\% of all genes) are differentially expressed between MG and Rb: 50 genes had higher expression at Rb than at MG and 70 genes had higher expression at MG than at Rb (Figure 3, list available in Additional File 1: Tables 1, 2).

\section{Gene expression according to quantity and type of symbiont at a vent field scale}

In order to identify genes potentially regulated by symbiont content and their respective activity, we conducted eight distinct analyses by classifying individuals according to their MOX and SOX content and ATP sulfurylase and pmoA expression levels for each population separately. For this study, the ratio of expression of each gene was calculated by dividing signal intensity of the gene for one given sample by the mean intensity of the gene in all samples from the same population. Our analyses indicated that symbiont quantity did not significantly affect the number of regulated genes (Table 2). One exception was observed for MOX quantity at MG, where a high MOX content regulated more genes than in mussels with a low MOX content (285

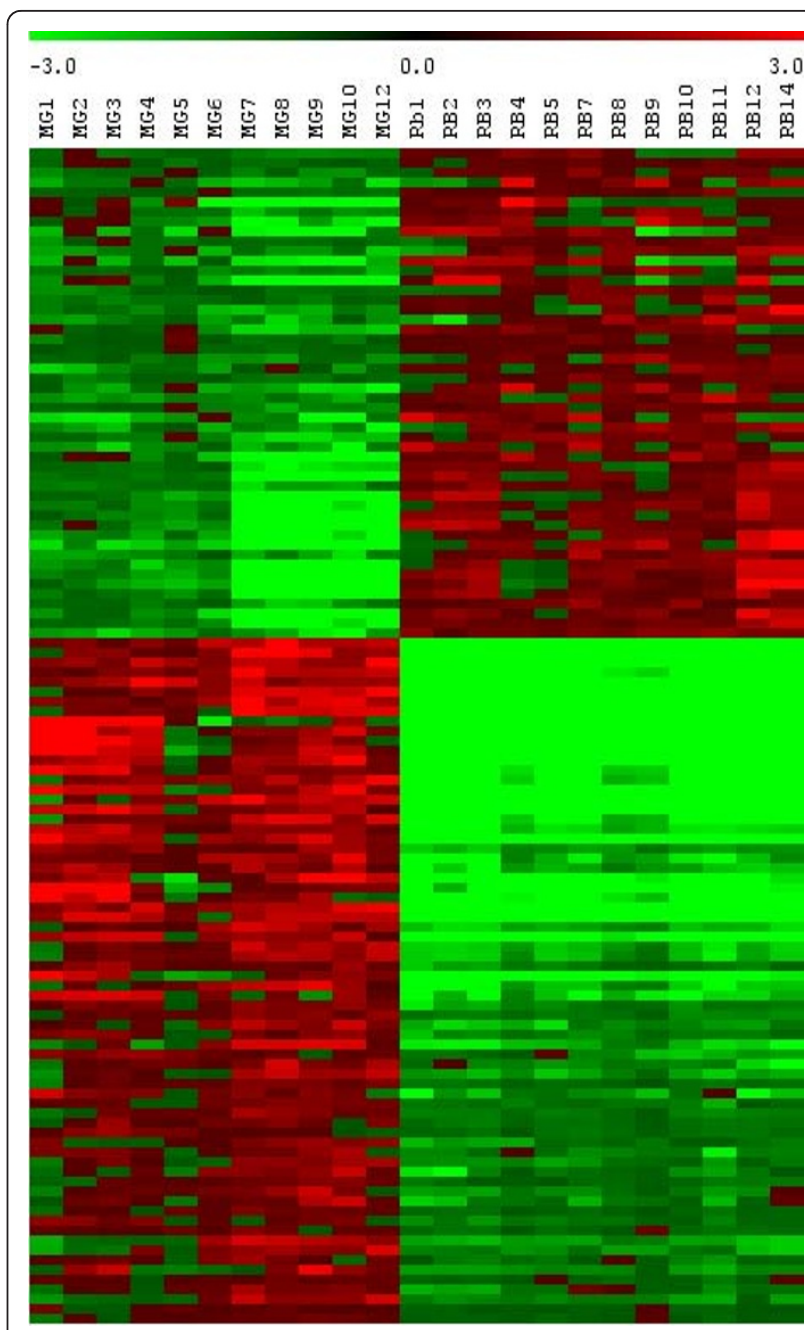

Figure 3 Gene expression differentially regulated between Menez Gwen and Rainbow vent fields according to SAM results obtained with $\mathrm{TmeV}$.

vs. 180, Table 2). We further analyzed the genes commonly regulated by both symbionts within each site. At the MG vent field, only $1 \%$ of all genes were regulated by SOX and MOX (Table 3), while $5.6 \%$ were regulated in mussels collected at $\mathrm{Rb}$ (Table 2). Interestingly, MOX symbiont impacted a higher proportion of genes than SOX in both vent fields $(14-20 \%$ vs. 8$16 \%$, Table 2), as well as genes commonly regulated by each symbiont in the two vent fields $(1.1 \%$ vs. $3 \%$ for SOX and MOX, respectively, Table 2). A list of regulated genes in all conditions is available in Additional File 1: Tables 3-14. Regarding symbiont gene expression, we obtained a result in accordance with symbiont quantity at each site: ATP sulfurylase expression is higher at MG where SOX are abundant and pmoA expression is higher at $\mathrm{Rb}$ where MOX are abundant (Table 1, Additional File 1: Tables 15-26). 
Table 2 Number of genes (and corresponding percentage to total number of genes) regulated by symbiont content within each vent field, commonly regulated by the two types of symbiont within vent field and by each type of symbiont across vent field

\begin{tabular}{|c|c|c|c|c|c|c|}
\hline \multirow{3}{*}{ Low SOX } & \multicolumn{2}{|c|}{ Menez Gwen } & \multicolumn{2}{|c|}{ Rainbow } & \multicolumn{2}{|c|}{ Regulated in the 2 vent fields } \\
\hline & 128 & & 286 & & & \\
\hline & & $8 \%$ & & $16 \%$ & 36 & $1.1 \%$ \\
\hline High SOX & 133 & & 259 & & & \\
\hline \multirow[t]{2}{*}{ Low MOX } & 180 & & 359 & & & \\
\hline & & $14 \%$ & & $20 \%$ & 102 & $3 \%$ \\
\hline High MOX & 285 & & 311 & & & \\
\hline \multicolumn{7}{|c|}{ Regulated by SOX and MOX } \\
\hline & 35 & $1 \%$ & 192 & $5.6 \%$ & 2 & $0.1 \%$ \\
\hline
\end{tabular}

\section{Discussion}

Deciphering effects of symbionts and environmental factors on gene expression in field populations of symbiotic organisms is an important goal in molecular ecology. In the case of the vent mussel B. azoricus, genes regulated and/or involved in its symbiotic relationship with two symbionts were unknown. To address this issue, we used a combination of subtractive libraries and a cDNA microarray approach to characterize putative differentially expressed genes in the hydrothermal vent mussel $B$. azoricus inhabiting two physically and chemically contrasting vent fields. Then, we determined if the expression of these differentially expressed genes was, in part, influenced by symbiont content and/or symbiont metabolism, and/or environmental factors. Because we used mussels collected in their natural environment, we did not expect to identify genes involved in the establishment of symbiosis, but rather genes involved in an established symbiosis that were differentially regulated with respect to symbiont type, quantity and activity, and environmental factors.

Vent field environmental conditions impact activity and relative abundance of both symbionts as well as host gene expression The quantification of symbiotic bacteria in mussel gills showed a significant difference of both SOX and MOX

Table 3 Number of genes (and corresponding percentage to total number of genes) regulated by symbiont activity within each vent field, and commonly regulated by both symbiont quantity and its corresponding activity

\begin{tabular}{lcccc}
\hline & \multicolumn{2}{c}{ Menez Gwen } & \multicolumn{2}{c}{ Rainbow } \\
\cline { 2 - 6 } Low ATP sulfurylase & 97 & & 91 & \\
High ATP sulfurylase & 195 & & 114 & \\
\hline Regulated by SOX and ATP sulfurylase & 17 & $0.5 \%$ & 17 & $0.5 \%$ \\
\cline { 2 - 6 } & 28 & & 180 & \\
Low pmoA & & $6 \%$ & & $10 \%$ \\
High pmoA & 172 & & 154 & \\
\hline Regulated by MOX and pmoA & 86 & $2.5 \%$ & 96 & $2.8 \%$ \\
\hline
\end{tabular}

content across the two vent fields. The relative abundance of the two symbionts is influenced by the hydrothermal fluid characteristics, especially methane and sulfide concentration. This correlation explains, for example, the higher abundance of MOX in mussels collected at $\mathrm{Rb}$ vent field where high concentrations of methane were detected $[27,28]$, compared to individuals from the MG vent field $[14,15,23]$. The average quantity of each symbiont was significantly different between the two vent fields, but we observed a large inter-individual variation in symbiont abundance within each field. This symbiotic plasticity allows mussels from one vent field to harbor the same amount and/or proportion of symbionts as mussels from another field. Mussels from each vent field were collected in a restricted area of the mussel bed, but given the highly chaotic mixing conditions encountered at hydrothermal vents, we have to consider variations in both sulfide and methane availability, even at the scale of the sampling patch. These variations in gas availability in vent fields impact the distribution and diet of vent fauna at a micro-spatial scale [19] and may explain these differences in symbiont content.

The symbiotic vent mussel B. azoricus inhabits a variable environment due to the highly chaotic mixing of hydrothermal fluid with seawater within the site $[29,30]$, and because of the bathymetric position of these hydrothermal fields [31]. Thus, a strong effect for environmental factors was expected due to the very different characteristics of the vent fluid in the two populations sampled (especially gas and heavy metals concentrations, temperature and pressure), and therefore specific signatures of the mRNA expression in mussels were expected for the different vent fields. Our microarray data showed that 120 genes $(3.5 \%$ of all genes) clearly distinguish both sites, indicating a relatively moderate effect of source vent on transcriptome regulation. However, cluster analysis of all individuals showed a clear separation between samples from MG and Rb, indicating that the physical characteristics of the two vent fields were strong enough to influence transcriptome expression in a way that distinguishes populations. 
Among the up-regulated genes in mussels collected at the Rainbow vent field, we identified a $60 \mathrm{~S}$ acidic ribosomal protein and a selenoprotein. The $60 \mathrm{~S}$ acidic ribosomal protein, known as a $\mathrm{P}$ protein, is mainly associated with the protein elongation step of translation, but potential roles in transcription, DNA repair [32], in response to pesticide exposure [33], and in intracellular iron sequestration [34] have also been described. The selenoprotein has multiple functions such as antioxidant defense, selenium transport and heavy metal chelation [35]. Up-regulation of these genes in mussels from the $\mathrm{Rb}$ vent field is consistent with the high metal concentrations at this site, the highest observed in the MAR hydrothermal area $[27,36]$.

Among the genes significantly up-regulated in mussels collected at the MG vent field, we identified some metabolic genes such as arginine kinase and carbonic anhydrase (CA). Arginine kinase is known to play a key role in cellular energy metabolism in invertebrates [37] and its regulation in response to temperature has been previously described in $B$. azoricus [25]. Carbonic anhydrase is known to be involved in the transfer of $\mathrm{CO}_{2}$ from the environment to the cell in many symbiotic animals. This enzyme catalyzes the reversible hydration of $\mathrm{CO}_{2}$, and was found to be regulated at the transcriptome level according to the state of symbiosis, in both plants and animals [38], but also in B. azoricus in response to temperature variations [25].

Regarding the limited number of known genes and the lack of experimental studies performed on B. azoricus in response to various stressors, as well as the lack of information about the micro-environmental characteristics around mussels (especially for concentrations of $\mathrm{H}_{2} \mathrm{~S}$ and $\mathrm{CH}_{4}$ ), it remains difficult to link these significantly regulated genes to environmental parameters. Moreover, our sampling strategy of collecting mussels directly from their environment did not allow us to assess a cause and effect relationship. For example, we cannot establish whether a change in environmental factors drives symbiont metabolism, and in turn host physiology; or conversely, if a change in environment directly effects host physiology leading to a regulation of symbiont population. This point will be discussed more extensively below.

\section{Do symbiotic bacteria drive gene expression in Bathymodiolus azoricus?}

Double symbiosis enables $B$. azoricus to colonize sulfide and/or methane rich environments, in which the primary production of the symbionts ensures a part of the host's nutrition. Additionally, these mussels are able to filter feed and can survive senescent vent conditions. Mixotrophy is a major advantage in highly variable environments. In the particular case of B. azoricus, the mussel has to host two different symbionts that are present in varying abundance in different individuals. The identification of genes showing a similar regulation according to SOX and/or MOX content in two contrasted populations should help to distinguish genes that are mainly regulated by symbiont content from those that are regulated by both symbiont content and environmental parameters. The microarray analysis showed a relatively low number of genes significantly regulated by either SOX (8\%) or MOX (14\%) content in the MG population compared to the $\mathrm{Rb}$ population which had $16 \%$ regulated by SOX content and $20 \%$ by MOX content. These results suggest that symbiont content is less influential on the transcriptome in mussels from MG. However, because of the lack of studies on this particular dual-symbiont model, we have no information about a potential competition between SOX and MOX symbionts, and in turn, how mussels control each kind of symbiont. One could hypothesize that this difference is partly due to the bathymetric position of the two vent fields. We noticed that very few genes seem to be commonly regulated by both SOX and MOX content at MG, only $1 \%$ of all genes, suggesting that each symbiont may affect different pathways in mussels inhabiting this vent field, compared to $\mathrm{Rb}$ where $5.6 \%$ of all genes are commonly influenced by SOX and MOX content. The MG vent field is located at a depth of $800 \mathrm{~m}$ versus $2300 \mathrm{~m}$ for the Rainbow vent field. Thus, the mussels at MG benefit from a higher particle flux [39] which lessens the contribution to carbon nutrition needed from the symbiont, and possibly also the impact of symbionts on the host's transcriptome. In contrast, the mussels at the deeper Rainbow vent field experience lower particle flux and rely more on symbionts to meet their carbon needs. The pattern of gene expression obtained in this study could reflect the relative carbon contribution of symbionts compared to the availability of particles to host nutrition.

While the number of sequences available for bivalves has increased dramatically during the past few years [40-43], very few genes are either fully annotated and/or functionally characterised, often leading to a mean proportion of unknown sequences higher than $50 \%$. In a bivalve such as $B$. azoricus, it is particularly difficult to find a relationship between the regulation of gene expression and a symbiotic state, even if the gene was described as involved in symbiosis-related functions in other organisms. However, we identified several genes previously described in host/symbiont relationships in other marine models, such as the sea anemone Anemonia viridis [8], the squid Euprymna scolopes [44], and the hydrothermal tubeworms Ridgeia piscesae and Riftia pachyptila [4,6], and one could hypothesize that their roles are potentially quite similar in hydrothermal 
mussels. It is, for example, well established that participation of sugar residues and lectins is a major process in host-microorganism recognition [45]. In this study, we identified five lectins belonging to different families and showing significant regulation according to symbiont quantity or activity. Lectins are known to bind carbohydrate structures on foreign cells [46,47]. Previous work conducted on corals [48] showed that specific lectins may bind to both pathogens and algal symbionts, suggesting that lectins may have been co-opted from an ancient innate immune system into a role of selecting and maintaining the photosynthetic endosymbionts in host tissues. In our analysis, we also identified a lysozyme and observed that this gene is more expressed in mussels with a high SOX content (MG vent field). The ancestral function of this enzyme is in defense against pathogens by degrading bacterial wall $[49,50]$, but its implication in digestion in ruminants [51] and mollusks [52] has also been demonstrated. Lysozyme is strongly involved in the control and maintenance of the bacterial flora in the aphid bacteriocytes [53] and in the digestion of chemoautotrophic bacteria by their deep-sea bivalve hosts [54]. This change of lysozyme function from antibiotic defense to digestion may have arisen through convergent evolution via positive selection [55]. An example of such change has been recently identified in the Eastern oyster, Crassostrea virginica in the i-type lysozymes family [52]. The regulation of lysozyme and lectins in $B$. azoricus agrees with previous observations, an indication that these two gene families are potentially good candidates for proteins that might be involved in the control and maintenance of symbionts. We also noticed the regulation of several genes directly or indirectly implicated in immune defense and inflammatory reaction. Among them are some receptors to melatonin [56], acetylcholine and laminin [57], synthaxin [58], kininogen, cystatin [59] and prostaglandin E2 synthetase and receptor [60], and all are significantly regulated by symbiont abundance and/or activity in B. azoricus. However, due to the multi-functionality of these proteins coupled with a lack of knowledge about their roles in hydrothermal mussels, we cannot be conclusive about their respective function(s) in the mussel/symbiont relationship. Complementary analyses of function and biochemical properties should help to determine to what extent these proteins are involved in the breakdown of symbionts and the elimination of microbial intruders in hydrothermal vent mussels.

The influence of bacteria on the cytoskeleton of host cells has been extensively studied in both host-pathogen interactions $[61,62]$, and host-symbiont relationships $[44,63,64]$. These studies showed that various pathogens and symbionts increase their intimacy with the host tissues by altering the host cytoskeleton. For example, several microfilament and microtubule proteins are strongly regulated at both RNA and protein stages during the establishment of the symbiotic association between the squid $E$. scolopes and Vibrio fischeri $[44,63]$. In B. azoricus, some genes encoding cytoskeleton proteins are differentially regulated according to symbiont content, suggesting a potential effect of symbionts on host cell structure. Among these genes, five (tubulin, dynein, annexin, betathymosin and actin-related protein 2/3) present an interesting pattern of up-regulation in mussels hosting a high symbiont content, especially those with a high MOX level.

\section{Disentangling environment and symbiont effects on host gene expression: what is the order of event?}

We established that the expression of several genes is correlated with either symbionts (quantity and/or activity) or environmental factors, but we were not able to determine which factor is directly responsible for transcriptome variations in mussels. The analysis of the transcriptome of a symbiotic organism often generates confusion when considering the combined effect of both symbionts and interrelated environmental factors. While they used a robust experimental design, DeSalvo et al. [65] were not able to determine if a thermal challenge changed coral (Montastraea faveolata) physiology which, in turn, induced a change in symbiont type dominance, or if a thermal stress directly changed symbiont type dominance and, in turn, the physiology of the host. In our case, we could assume that environmental factors directly influenced symbiont abundance in mussels [present study; [23]]. But we also observed a large inter-individual variation in symbiont abundance (measured at both sites), indicating that environmental factors alone do not drive symbiont quantity, but probably in association with host and/or symbiont need and/or physiological state.

The expression pattern of several genes was also ambiguous. For example, ferritins are significantly regulated by symbiont content in both populations of vent mussels, and their regulation in host-pathogen as well as in host-symbiont interactions has been previously demonstrated $[66,67]$. But ferritins are also known to play a pivotal role in iron homeostasis and the oxidative stress response. In our study, ferritins are more expressed in mussels harboring high SOX and MOX content collected at $\mathrm{Rb}$ vent field, compared to MG mussels in which ferritins are more expressed in low MOX content mussels. In this case, it was not possible to link the ferritin expression pattern to either symbiont content or the high level of iron measured at $\mathrm{Rb}$ vent field. A similar analysis applies to carbonic anhydrase (CA). We showed that CA is regulated by environmental factors (see discussion above). But, it has previously been demonstrated that CA plays a major role in transport and supply of $\mathrm{CO}_{2}$ to autotrophic symbionts 
housed in host tissues, such as in the two hydrothermal worms $R$. pachyptila and $R$. piscesae [6,68-70]. In these two species, the metabolism of the thiotrophic symbionts (sulphide oxidation) entails a fast and high production of protons, with which the worms have to cope, partly by induction of CA at both the level of enzymatic activity and mRNA expression. In our study, we observed that CA is highly expressed in the mussels collected at MG in which a higher SOX content was observed compared to Rb.

\section{Conclusion}

In this study, we derived a list of candidate genes whose evolutionary trajectory in symbiont acquisition and host mechanisms for symbiont content regulation can now be explored. We also showed that in B. azoricus, the transcriptome appears to be regulated by symbiont content with a strong effect of vent field characteristics. However, we do not exclude that some of the genes in this study identified as being regulated could also be associated with parameters other than symbiont content and environment. Sampling and transport to the surface can modify transcriptome expression. However, we submit that those effects would be similar for all samples, mitigating their effect on the analysis. Adaptive evolution at the molecular level is more likely to be discovered from genes associated with regulatory networks underlying the expression of symbiosis related genes. Our study has produced a preliminary description of a transcriptomic response in a hydrothermal mussel symbiotic model, which we hope can help identify genes that progressively evolved to be involved in the acquisition and regulation of symbiosis on both ecological and evolutionary timescales.

\section{Methods}

\section{Biological samples}

The hydrothermal vent mussels, B. azoricus, were collected during the MoMARETO cruise [71] along the MidAtlantic Ridge with the N/O Pourquoi Pas? and ROV Victor 6000. Samples were collected at three vent fields, MG $\left(37^{\circ} 50^{\prime} \mathrm{N}, 31^{\circ} 31^{\prime} \mathrm{W} ; \mathrm{n}=25\right)$, LS ( $37^{\circ} 17^{\prime} \mathrm{N}, 32^{\circ} 17^{\prime} \mathrm{W} ; \mathrm{n}=$ $30)$ and $\mathrm{Rb}\left(36^{\circ} 14^{\prime} \mathrm{N}, 33^{\circ} 54^{\prime} \mathrm{W} ; \mathrm{n}=25\right)$, which have contrasting physical and chemical characteristics (Table 1). Samples were collected at the end of the dive, kept in hermetic boxes containing vent seawater, brought onboard about 1.5 hours later, and immediately measured and dissected to minimize sampling effect. Harvested gill tissues were swiftly frozen in liquid nitrogen.

\section{Detection of symbiont quantity and symbiont gene expression by real-time PCR Symbiont quantification}

Genomic DNA of both mussel and bacteria was extracted together from gill tissue using a CTAB/PVP extraction procedure (2\% CTAB, $1 \% \mathrm{PVP}, 1.4 \mathrm{M} \mathrm{NaCl}$, $0.2 \%^{\circledR}$-mercaptoethanol, $100 \mathrm{mM}$ Tris $\mathrm{HCl} \mathrm{pH8}, 0.1 \mathrm{mg}$. $\mathrm{mL}^{-1}$ proteinase $\mathrm{K}, 1 \mathrm{mg} \cdot \mathrm{mL}^{-1}$ lysozyme). After complete digestion of tissues $\left(1 \mathrm{~h}\right.$ at $\left.60^{\circ} \mathrm{C}\right)$, the mixture was incubated with $1 \mu \mathrm{L}$ of RNase for $30 \mathrm{~min}$ at $37^{\circ} \mathrm{C}$. An equal volume of chloroform-isoamyl alcohol (24:1) was then added and tubes were slowly mixed by inversion for 3 min before a 10 min centrifugation at $14,000 \mathrm{rpm}$ and $4^{\circ} \mathrm{C}$. The supernatant was collected in a fresh tube, and DNA was precipitated with $2 / 3$ volume of cold isopropanol $\left(1 \mathrm{~h}\right.$ at $\left.-20^{\circ} \mathrm{C}\right)$. The DNA pellet was recovered by centrifugation $\left(14,000 \mathrm{rpm}\right.$ at $4^{\circ} \mathrm{C}$ for $\left.20 \mathrm{~min}\right)$, washed with $75 \%$ cold ethanol, air-dried and suspended in 100 $\mu \mathrm{L}$ of sterile water. Genomic DNA from muscle was extracted by using the same protocol and used as a negative control in real-time PCR amplification. The relative quantity of symbionts was estimated by realtime PCR amplification using $16 \mathrm{~S}$ specific primers designed according to the probes developed previously for FISH analysis [15] (Table 4). All experiments were carried out using a Chroma4 thermal cycler (Bio-Rad Laboratories Inc, Hercules, $\mathrm{CA}$ ) and $1 \times$ ABsolute ${ }^{\mathrm{TM}} \mathrm{QPCR}$ SYBR ${ }^{\circledR}$ Green mix (ABgene, Epsom, UK), $70 \mathrm{nM}$ of each primer, and diluted DNA (2.5 ng) in a final volume of $10 \mu \mathrm{l}$. A $120 \mathrm{bp}$-fragment of cytosolic malate dehydrogenase gene (MDH) from the host was used as an internal PCR control (Table 4). The relative quantity of each symbiont type was estimated by using the comparative $\mathrm{Ct}$ method using the formula: $\mathrm{RQ}=2^{-}$ $\otimes \mathrm{Ct}\left(\otimes \mathrm{Ct}=\mathrm{Ct}_{165}-\mathrm{Ct}_{\mathrm{MDH}}\right)$. No amplification of MOX or SOX 16S was recorded when muscle genomic DNA (negative control) was used in amplification reactions. Significant differences in bacteria content between vent fields were detected with a nonparametric WilcoxonMann-Whitney test with multiple test correction of Holm [72] (R-language 'stats' package).

\section{Symbiont gene expression}

We study the expression of two bacterial genes, the ATP sulfurylase which is specific to SOX and catalyses the reaction of sulfate at the expense of ATP to generate adenosine phosphosulfate and the particulate methane monoxygenase pmoA which is specific to MOX and involved in methane oxidation) was followed to estimate the activity of each symbiont. Total RNA of both mussels and bacteria was extracted together from gill tissue by using Tri-Reagent (Sigma, St. Louis, MO) according to the manufacturer's instructions. Five $\mu \mathrm{g}$ of total RNA were reverse transcripted using M-MLV reverse transcriptase (Promega, Madison, WI), random hexamers (Promega) and an anchor-oligo(dT) primer (5'CGCTCTAGAACTAGTGGATCT $\left._{(17)}\right)^{\prime}$ ). The relative gene expression of symbionts was estimated by realtime PCR amplification using specific ATP sulfurylase and pmoA primers (Table 4; GenBank accession 
Table 4 Primers used in real-time PCR amplification of bacteria and host gene.

\begin{tabular}{|c|c|}
\hline Gene & Primer sequence $5^{\prime}-3^{\prime}$ \\
\hline \multirow[t]{2}{*}{ Sulfide oxidizer symbiont $16 \mathrm{~S}$} & Forward GAGTAACGCGTAGGAATCTGC \\
\hline & Reverse CGAAGGTCCTCCACTITACTCCATAGAG \\
\hline \multirow[t]{2}{*}{ Methanotrophic symbiont $16 \mathrm{~S}$} & Forward GTGCCAGCMGCCGCGGTAA \\
\hline & Reverse GCTCCGCCACTAAGCCTATAAATAGACC \\
\hline \multirow[t]{2}{*}{ Cytosolic malate dehydrogenase (host) } & Forward ATGGAGGAAAGAGATATGGCACTGAGCGT \\
\hline & Reverse TAACATTAAACATAGCCTAGGAACCTAATG \\
\hline \multirow[t]{2}{*}{ ATP sulfurylase $(\mathrm{SOX})$} & Forward GTGCGTGATGCCGCTATCCGCACCATG \\
\hline & Reverse GGTCCGGCATAGAGCATGTCAAACGGATA \\
\hline \multirow[t]{2}{*}{ Particulate methane monooxygenase $\mathbf{A}(\mathrm{MOX})$} & Forward GAGTGGATTAACAGATATTTGAACTTCTGG \\
\hline & Reverse CATACCACCAACAACAGCTGTAAGTACAAA \\
\hline \multirow[t]{2}{*}{ Ribosomal protein L15 (host) } & Forward TATGGTAAACCTAAGACACAAGGAGT \\
\hline & Reverse TGGAATGGATCAATCAAAATGATTTC \\
\hline
\end{tabular}

numbers AB178052 and AY945761, respectively). A volume of $4.6 \mu \mathrm{l}$ of each diluted reverse transcription product $(1: 20)$ was subjected to real-time PCR in a final volume of $10 \mu \mathrm{l}$ containing $70 \mathrm{nM}$ of primers and $1 \times$ ABsolute $^{\mathrm{TM}}$ QPCR SYBR ${ }^{\circledR}$ Green Mix (ABgene). The amplification was carried out as follows: initial enzyme activation at $94^{\circ} \mathrm{C}$ for $15 \mathrm{~min}$, then 40 cycles of $94^{\circ} \mathrm{C}$ for $15 \mathrm{sec}$ and $60^{\circ} \mathrm{C}$ for $1 \mathrm{~min}$. A fragment of ribosomal protein L15 gene (RpL15) from the host was used as an internal PCR control (Table 4). Relative expression of each gene was calculated according to comparative $\mathrm{Ct}$ method using the formula: $\mathrm{RQ}=2^{-\otimes \mathrm{Ct}}\left(\otimes \mathrm{Ct}=\mathrm{Ct}_{\mathrm{ATP}}\right.$ sulf or pmoA $\left.-C t_{R p L 15}\right)$. Significant differences in bacteria gene expression between vent fields were detected by using a non parametric Wilcoxon Mann-Whitney test with multiple test correction of Holm [72] (R package).

\section{Suppressive Subtraction Hybridization (SSH)}

Mussels from three hydrothermal vent fields Menez Gwen, Lucky Strike and Rainbow have been used in the SSH design in order to optimize the chance to characterize genes potentially regulated by symbiont content but also by environmental parameters. Total RNA was isolated from frozen gill tissues with Tri Reagent following the manufacturer's instructions (Sigma). Four mussel groups, named $\mathrm{S}+(\mathrm{n}=3$, high $\mathrm{SOX}$ content $), \mathrm{M}+(\mathrm{n}=$ 3 , high MOX content), $\mathrm{M}-(\mathrm{n}=3$, low MOX content) and SM- ( $\mathrm{n}=8$, low SOX and MOX content), were created based on their respective bacteria content (Figure 1) and used in the following suppression subtraction hybridization (SSH) design: $\mathrm{S}_{+} \leftrightarrow \mathrm{M}+, \mathrm{S}_{+} \leftrightarrow \mathrm{M}-, \mathrm{S}_{+} \leftrightarrow$ SM-, M+ $\leftrightarrow$ M- and $M+\leftrightarrow$ SM-, with $S(+/-)$ and $M$ $(+/-)$ designated the level of SOX and MOX, respectively. Poly $(\mathrm{A}+)$ RNA were isolated from each of the 4 pools of total RNA using the PolyATract ${ }^{\circledR}$ mRNA Isolation system (Promega) following the manufacturer's instructions. The SSH were obtained by using the PCRSelect $^{\mathrm{TM}}$ cDNA Subtraction kit (Clontech, Mountain
View, CA), amplified with Advantage ${ }^{\circledR}$ cDNA PCR kit, and finally cloned into pGEM ${ }^{\circledR}-\mathrm{T}$ vector (Promega) following the manufacturer's instructions. The ligation mixtures were used to transform DH5 $\langle E$. coli competent cells and colonies were then grown in liquid ampicillinLB medium supplemented with $7.5 \%$ glycerol. Bacteria cultures were transferred to 384-plates and the sequencing of a total of 3840 clones was performed at Genoscope (Evry, France) using an ABI 3730 automatic capillary sequencer and the ABI BigDye Terminator v.3.1 sequencing kit.

\section{Sequence annotation}

Prior to clustering and contig construction, the sequence traces were analyzed and trimmed of low quality 5' and 3' extremities (quality value $<15$ ), using the phred software $[73,74]$. Sequences were cleaned to remove low complexity regions, short length (<100 bp), and vector and adaptor sequence using seqclean [75]. Clustering and contig construction was performed using the TGICL software from TIGR [75]. Contig and singleton sequences were compared to protein sequences of the UniprotKB database [76] using BLASTX [77]. Coding frames were deduced from BLASTX best hit alignments (E-value $\leq 1 \mathrm{e}-03)$ and the CDS were created according to the protocol detailed in Gagniere et al. [78]. The protein sequences were then aligned to their homologs using the PipeAlign toolkit [79]. Gene Ontology (GO) [80] annotations for the B. azoricus sequences were provided by GOAnno [81] after analysis of the GO terms mined from the protein family.

cDNA microarray preparation, hybridization and analysis For this study, we used a microarray containing 3425 clones from $B$. azoricus: clones issued from the present SSH libraries and from a previous cDNA library [41]. Protocols for slide printing, hybridization and analysis of the microarray were carried out according 
to those established by the Plateforme Puces à ADN (Biogenouest ${ }^{\circledR}$, Nantes, France, http://cardioserve. nantes.inserm.fr/ptf-puce). All clones have been submitted to PCR and purified according to standard protocols. Microarray slides were then printed with a Lucidea Arrayer (Amersham) on Epoxy slides. Each slide contained a total of 3425 features spotted. Printed slides were stored in a dark cool dry location until use.

\section{Microarray hybridizations}

A quantity of $20 \mu \mathrm{g}$ of total RNA of each sample was directly labeled by reverse transcription (using random hexamer and $\mathrm{dT}$ primer) using a master mix containing $1 \mathrm{nmol}$ of Cy5 or Cy3 dUTP (GE Healthcare). A loop design was used (one individual from Menez Gwen vent field against one individual from Rainbow vent field) in order to generate a replicate for each sample (dye swap). Following RT, single-stranded RNA was treated with RNAse A. Then, RT reactions were cleaned using Illustra CyScribe GFX purification Kit (GE Healthcare). Equimolar amounts of cDNA from both samples were mixed in a single pool with hybridization buffer, boiled for $2 \mathrm{~min}$ at $99^{\circ} \mathrm{C}$ then placed at $37^{\circ} \mathrm{C}$ for $30 \mathrm{~min}$. Hybridization took place in Corning hybridization chambers overnight at $42^{\circ} \mathrm{C}$. Microarrays were washed once in $2 \times$ SSC and $0.1 \%$ SDS followed by a rinse in $1 \times$ SSC and two rinses in $0.2 \times$ SSC and finally dried by centrifugation.

\section{Microarray scanning and normalization}

Slides were immediately scanned after centrifugation using an Axon 4000B scanner (Axon Instruments Inc.) with standard dual laser excitation at $532 \mathrm{~nm}(17 \mathrm{~mW})$ and $635 \mathrm{~nm}(10 \mathrm{~mW})$ according to the following parameters: Cy 5 Photo Multiplier Tube (PMT) 570 and Cy 3 PMT 610. This process was repeated for each of the 24 hybridized slides with a $5-\mu \mathrm{m}$ resolution mode. The images (16-bit TIF images) were then analyzed with Genepix pro 5.1 software (Axon Instruments Inc.) according to the manufacturer's instructions. The spot density files output from GenePix Pro 6.0 were analyzed by eyes to remove bad spots. The normalization was then carried out using the programming language $\mathrm{R} /$ BioConductor [82] and Limma library [83]. The background correction of the probe intensity was carried out using the normexp method [84]. Then lowess normalization, intra- and inter-slide normalization were applied to remove intensity dependent trends. Replicated values of each gene were then averaged. The data obtained from the microarray and used in the following analysis have been deposited in Gene Expression Omnibus (GEO) at the National Center for Biotechnology Information (NCBI), with the series accession number (under process).

\section{Microarray data analysis}

All genes kept for analysis were used for hierarchical clustering analysis using TmeV [85] (http://www.tm4. org/mev.html) with Pearson correlation and complete linkage clustering parameters. KMC support parameters were used to identify clusters of genes that behave most similarly in all samples. Differentially expressed genes were identified by significance analysis of microarray using a fold-change of 2. False-discovery rate is estimated by analyzing permutations of the measurements and expresses the percentage of genes identified as significant by chance for a given value of a threshold parameter delta. This rate was manually adjusted to zero in order to only include a reasonable number of candidate genes with acceptable and well-defined error probabilities.

\section{Additional material}

\section{Additional file 1: Tables including showing genes presenting a} differential expression in the analyses conducted (SOX/MOX content and quantity, hydrothermal vent origin).

\section{Acknowledgements}

We thank the crew and pilots of the NO Pourquoi Pas? and the ROV Victor6000 for their assistance and technical support, as well as the chief scientist Jozée Sarrazin and Pierre-Marie Sarradin, during the cruise MOMARETO 2006. We thank Isabelle Guisle and the Plateforme Puces à ADN (Biogenouest ${ }^{\circledR}$, Nantes, France) for microarray printing. We also thank Didier Jollivet for helpful discussion during the preparation of this manuscript. We are grateful to Brenda J. Landau for an English proofreading of this article. This work and IB post-doc financial support were funded by the ANR program Deep Oases (ANR-06-BDV-005), the GDR 2907 IFREMER/CNRS ECCHIS and the JST CNRS program "Bathymodiolus".

\section{Author details}

1CNRS, UMR 7144, Adaptation et Diversité en Milieu Marin, Station Biologique de Roscoff, 29682 Roscoff, France. ${ }^{2}$ UPMC Université Paris 06, Station Biologique de Roscoff, 29682 Roscoff, France. ${ }^{3}$ Department of Structural Biology and Genomics, Institut de Génétique et de Biologie Moléculaire et Cellulaire (IGBMC), INSERM U596, UMR CNRS 7104, Faculté des Sciences de la Vie, Université de Strasbourg, 67000 Strasbourg, France. ${ }^{4}$ Génoscope, Centre National de Séquençage, UMR CNRS 8030, 2 Gaston Crémieux, CP 5706, 91507 Evry, France. ${ }^{5}$ Service Informatique et Génomique FR2424, Analysis and Bioinformatics for Marine Science Platform (ABiMS), Station Biologique de Roscoff, 29682 Roscoff, France.

\section{Authors' contributions}

IB and AT conceived and supervised the study. RR, OL and EC analysed the sequence data. RR and $\mathrm{OL}$ developed the web-data base. IB analysed the microarray data and wrote the manuscript. CD produced all sequences. AT participated to the microarray construction. FL supervised the study and participated in its coordination. All authors read and approved the final manuscript.

Received: 29 June 2011 Accepted: 28 October 2011 Published: 28 October 2011

\section{References}

1. Moran NA: Symbiosis as an adaptive process and source of phenotypic complexity. Proc Natl Acad Sci USA 2007, 104(Suppl 1):8627-8633. 
2. Margulis L, Sagan D: Acquiring genomes: A theory of the origins of species. Basic Books, New York; 2002.

3. Dubilier N, Bergin C, Lott C: Symbiotic diversity in marine animals: the art of harnessing chemosynthesis. Nat Rev Microbiol 2008, 6:725-740.

4. Sanchez S, Hourdez S, Lallier FH: Identification of proteins involved in the functioning of Riftia pachyptila symbiosis by Subtractive Suppression Hybridization. BMC Genomics 2007, 8:337.

5. deBoer ML, Krupp DA, Weis MV: Proteomic and transcriptional analyses of coral larvae newly engaged in symbiosis with dinoflagellates. Comp Biochem Physiol 2007, 2D:63-73.

6. Nyholm SV, Robidart J, Girguis PR: Coupling metabolite flux to transcriptomics: insights into the molecular mechanisms underlying primary productivity by the hydrothermal vent tubeworm Ridgeia piscesae. Biol Bull 2008, 214:255-265.

7. Sunagawa S, Wilson EC, Thaler M, Smith ML, Caruso C, Pringle JR, Weis VM, Medina M, Schwarz JA: Generation and analysis of transcriptomic resources for a model system on the rise: the sea anemone Aiptasia pallida and its dinoflagellate endosymbiont. BMC Genomics 2009, 10:258.

8. Sabourault C, Ganot P, Deleury E, Allemand D, Furla P: Comprehensive EST analysis of the symbiotic sea anemone, Anemonia viridis. BMC Genomics 2009, 10:333.

9. Voolstra CR, Schwarz JA, Schnetzer J, Sunagawa S, Desalvo MK, Szmant AM, Coffroth MA, Medina M: The host transcriptome remains unaltered during the establishment of coral-algal symbioses. Mol Ecol 2009, 18:1823-1833.

10. Vidal-Dupiol J, Adjeroud M, Roger E, Foure L, Duval D, Mone Y, FerrierPages C, Tambutte E, Tambutte S, Zoccola D, Allemand D, Mitta G: Coral bleaching under thermal stress: putative involvement of host/symbiont recognition mechanisms. BMC Physiol 2009, 9:14.

11. Childress JJ, Fisher CR, Brooks JM, Kennicutt MC, Bidigare R, Anderson AE: A methanotrophic marine molluscan (Bivalvia, Mytilidae) symbiosis: mussels fuelled by gas. Science 1986, 233:1306-1308.

12. Nelson DC, Hagen KD, Edwards DB: The gill symbiont of the hydrothermal vent mussel Bathymodiolus thermophilus is a psychrophilic, chemoautotrophic, sulfur bacterium. Mar Biol 1995, 121:487-495.

13. Cavanaugh CM, Levering PR, Maki JS, Mitchell R, Lidstrom ME: Symbiosis of methylotrophic bacteria and deep-sea mussels. Nature 1987, 325:346-348.

14. Fiala-Médioni A, McKiness ZP, Dando P: Ultrastructural, biochemical, and immunological characterization of two populations of the mytilid mussel Bathymodiolus azoricus from the Mid-Atlantic Ridge: evidence for a dual symbiosis. Mar Biol 2002, 141:1035-1043.

15. Duperron S, Bergin C, Zielinski F, Blazejak A, Pernthaler A, McKiness ZP, DeChaine $\mathrm{E}$, Cavanaugh CM, Dubilier N: A dual symbiosis shared by two mussel species, Bathymodiolus azoricus and Bathymodiolus puteoserpentis (Bivalvia: Mytilidae), from hydrothermal vents along the northern MidAtlantic Ridge. Environ Microbiol 2006, 8:1441-1447.

16. Duperron S, Lorion J, Samadi S, Gros O, Gaill F: Symbioses between deepsea mussels (Mytilidae: Bathymodiolinae) and chemosynthetic bacteria: diversity, function and evolution. C R Biol 2009, 332:298-310.

17. Page HM, Fiala-Medioni A, Fisher CR, Childress JJ: Experimental-evidence for filter-feeding by the hydrothermal vent mussel, Bathymodiolus thermophilus. Deep Sea Res 1991, 38A:1455-1461.

18. Salerno JL, Macko SA, Hallam SJ, Bright M, Won YJ, McKiness Z, Van Dover CL: Characterization of symbiont populations in life-history stages of mussels from chemosynthetic environments. Biol Bull 2005, 208:145-155

19. De Busserolles F, Sarrazin J, Gauthier O, Gélinas Y, Fabri MC, Sarradin PM, Desbruyères D: Are spatial variations in the diets of hydrothermal fauna linked to local environmental conditions? Deep Sea Res II 2009, 56:1649-1664.

20. Fisher $C R$, Childress JJ: Organic carbon transfer from methanotrophic symbionts to the host hydrocarbon-seep mussel. Symbiosis 1992, 12:221-235.

21. Elsaied HE, Kaneko R, Naganuma T: Molecular characterization of a deepsea methanotrophic mussel symbiont that carries a RuBisCO gene. Mar Biotechnol 2006, 8:511-520.

22. Duperron S, Sibuet M, MacGregor BJ, Kuypers MM, Fisher CR, Dubilier N: Diversity, relative abundance and metabolic potential of bacterial endosymbionts in three Bathymodiolus mussel species from cold seeps in the Gulf of Mexico. Environ Microbiol 2007, 9:1423-1438.
23. Halary S, Riou V, Gaill F, Boudier T, Duperron S: 3D FISH for the quantification of methane- and sulphur-oxidizing endosymbionts in bacteriocytes of the hydrothermal vent mussel Bathymodiolus azoricus. ISME J 2008, 2:284-292

24. Fielman KT, Marsh AG: Genome complexity and repetitive DNA in metazoans from extreme marine environments. Gene 2005, 362:98-108.

25. Boutet I, Tanguy A, Le Guen D, Piccino P, Hourdez S, Legendre P, Jollivet D: Global depression in gene expression as a response to rapid changes of temperature in the hydrothermal vent mussel Bathymodiolus azoricus. Proc R Soc B 2009, 276:3071-3079.

26. Boutet I, Jollivet D, Shillito B, Moraga D, Tanguy A: Molecular identification of differentially regulated genes in the hydrothermal-vent species Bathymodiolus thermophilus and Paralvinella pandorae in response to temperature: a comparative study. BMC Genomics 2009, 10:222.

27. Douville E, Charlou JL, Oelkers EH, Bienvenu P, Jove Colon CF, Donval JP, Fouquet $Y$, Prieur D, Appriou P: The rainbow vent fluids $\left(36^{\circ} 14^{\prime} \mathrm{N}, \mathrm{MAR}\right)$ the influence of ultramafic rocks and phase separation on trace metal content in Mid-Atlantic Ridge hydrothermal fluids. Chem Geol 2002, 184:37-48.

28. Charlou JL, Donval JP, Fouquet $Y$, Jean-Baptiste P, Holm N: Geochemistry of high $\mathrm{H}_{2}$ and $\mathrm{CH}_{4}$ vent fluids issuing from ultramafic rocks at the Rainbow hydrothermal field ( $36^{\circ} 14^{\prime} \mathrm{N}$, MAR). Chem Geol 2002, 191:345-359.

29. Johnson KS, Childress JJ, Beehler CL, Sakamoto CM: Biogeochemistry of hydrothermal vent mussel communities: the deep-sea analogue to the intertidal zone. Deep Sea Res / 1994, 41:993-1011.

30. Sarradin PM, Waeles M, Bernagout S, Le Gall C, Sarrazin J, Riso R: Speciation of dissolved copper within an active hydrothermal edifice on the Lucky Strike vent field (MAR, 37 degrees N). Sci Tot Environ 2009, 407:869-878.

31. Colaço A, Bustamante P, Fouquet Y, Sarradin PM, Serrao-Santos R: Bioaccumulation of $\mathrm{Hg}, \mathrm{Cu}$ and $\mathrm{Zn}$ in the Azores triple junction hydrothermal vent field food web. Chemosphere 2006, 65:2260-2267.

32. Tchórzewski M: The acidic ribosomal P proteins. Int I Biochem Cell Biol 2002, 34:911-915.

33. Collin H, Meistertzheim AL, David E, Moraga D, Boutet I: Response of the Pacific oyster Crassostrea gigas, Thunberg 1793, to pesticide exposure under experimental conditions. J Exp Biol 2010, 213:4010-4017.

34. Furukawa T, Uchiumi T, Tokunaga R, Taketani S: Ribosomal protein-P2, a novel iron-binding protein. Arch Biochem Biophys 1992, 298:182-186.

35. Chen J, Berry MJ: Selenium and selenoproteins in the brain and brain diseases. J Neurochem 2003, 86:1-12.

36. Desbruyères $D$, Almeida $A$, Biscoito $M$, Comtet $T$, Khripounoff $A$, Le Bris $N$, Sarradin PM, Segonzac M: A review of the distribution of hydrothermal vent communities along northern mid-Atlantic Ridge: dispersal vs. environment controls. Hydrobiologia 2000, 440:201-216.

37. Strong SJ, Ellington WR: Isolation and sequence analysis of the gene for arginine kinase from the chelicerate arthropod, Limulus polyphemus: insights into catalytically important residues. Biochim Biophys Acta 1995, 1246:197-200.

38. Kochevar RE, Childress JJ: Carbonic anhydrase in deep-sea chemoautotrophic symbioses. Mar Biol 1996, 125:375-383.

39. Riou V, Colaço A, Bouillon S, Khripounoff A, Dando PR, Mangion P, Chevalier E, Korntheuer M, Serrão Santos R, Dehairs FA: Mixotrophy in the deep sea: a dual endosymbiotic hydrothermal mytilid assimilates dissolved and particulate organic matter. Mar Ecol Prog Ser 2010, 405:187-201.

40. Saavedra C, Bachère E: Bivalve genomics. Aquaculture 2006, 256:1-14.

41. Tanguy A, Bierne N, Saavedra C, Pina B, Bachère E, Kube M, Bazin E, Bonhomme F, Boudry P, Boulo V, Boutet I, Cancela L, Dossat C, Favrel P, Huvet $A$, Jarque $S$, Jollivet $D$, Klages $S$, Lapègue $S$, Leite $R$, Moal J, Moraga D, Reinhardt R, Samain JF, Zouros E, Canario A: Increasing genomic information in bivalves through new EST collections in four species: development of new genetic markers for environmental studies and genome evolution. Gene 2008, 408:27-36

42. Fleury $E$, Huvet $A$, Lelong $C$, de Lorgeril J, Boulo V, Gueguen $Y$, Bachère $E$, Tanguy A, Moraga D, Fabioux C, Lindeque P, Shaw J, Reinhardt R, Prunet P, Davey G, Lapègue S, Sauvage C, Corporeau C, Moal J, Gavory F, Wincker P, Moreews F, Klopp C, Mathieu M, Boudry P, Favrel P: Generation and analysis of a 29,745 unique Expressed Sequence Tags from the Pacific oyster (Crassostrea gigas) assembled into a publicly accessible database: the GigasDatabase. BMC Genomics 2009, 10:341. 
43. Bettencourt R, Pinheiro M, Egas C, Gomes P, Afonso M, Shank T, Santos RS High-throughput sequencing and analysis of the gill tissue transcriptome from the deep-sea hydrothermal vent mussel Bathymodiolus azoricus. BMC Genomics 2010, 11:559.

44. Wier AM, Nyholm SV, Mandel MJ, Massengo-Tiassé RP, Schaefer AL, Koroleva I, Splinter-Bondurant S, Brown B, Manzella L, Snir E, Almabrazi H, Scheetz TE, Bonaldo Mde F, Casavant TL, Soares MB, Cronan JE, Reed JL, Ruby EG, McFall-Ngai MJ: Transcriptional patterns in both host and bacterium underlie a daily rhythm of anatomical and metabolic change in a beneficial symbiosis. Proc Natl Acad Sci USA 2010, 107:2259-2264.

45. Chaston J, Goodrich-Blair H: Common trends in mutualism revealed by model associations between invertebrates and bacteria. FEMS Microbiol Rev 2010, 34:41-58.

46. Zelensky AN, Gready JE: The C-type lectin-like domain superfamily. FEBS J 2005, 272:6179-6217.

47. Robinson MJ, Sancho D, Slack EC, LeibundGut-Landmann S, Sousa CRE: Myeloid C-type lectins in innate immunity. Nat Immunol 2006, 7:1258-1265.

48. Kvennefors ECE, Leggat W, Hoegh-Guldberg O, Degnan BM, Barnes AC: An ancient and variable mannose-binding lectin from the coral Acropora millepora binds both pathogens and symbionts. Dev Comp Immunol 2008, 32:1582-1592.

49. Jollès P, Jollès J: What's new in lysozyme research? Mol Cell Biochem 1984, 63:165-189.

50. Yue X, Liu B, Xue Q: An i-type lysozyme from the Asiatic hard clam Meretrix meretrix potentially functioning in host immunity. Fish Shellfish Immunol 2011, 30:550-558.

51. Dobson DE, Prager EM, Wilson AC: Stomach lysozymes of ruminants. I. Distribution and catalytic properties. J Biol Chem 1984, 259:11607-16.

52. Xue Q, Hellberg ME, Schey KL, Itoh N, Eytan Rl, Cooper RK, La Peyre JF: A new lysozyme from the eastern oyster, Crassostrea virginica, and a possible evolutionary pathway for i-type lysozymes in bivalves from host defense to digestion. BMC Evol Biol 2010, 10:213.

53. Nakabachi A, Shigenobu S, Sakazume N, Shiraki T, Hayashizaki Y, Carninci $P$, Ishikawa H, Kudo T, Fukatsu T: Transcriptome analysis of the aphid bacteriocyte, the symbiotic host cell that harbors an endocellular mutualistic bacterium, Buchnera. Proc Natl Acad Sci USA 2005, 102:5477-5482.

54. Jollès J, Fiala-Médioni $A$, Jollès $P$ : The ruminant digestion model using bacteria already employed early in evolution by symbiotic molluscs. J Mol Evol 1996, 43:523-527.

55. Yang Z: Likelihood ratio tests for detecting positive selection and application to primate lysozyme evolution. Mol Biol Evol 1998, 15:568-573.

56. Carrillo-Vico A, Guerrero JM, Lardone PJ, Reiter RJ: A review of the multiple actions of melatonin on the immune system. Endocrine 2005, 27:189-200.

57. Kaloyianni M, Ragia V, Tzeranaki I, Dailianis S: The influence of $\mathrm{Zn}$ on signaling pathways and attachment of Mytilus galloprovincialis haemocytes to extracellular matrix proteins. Comp Biochem Physiol 2006, 144C:93-100

58. Erbs G, Molinaro A, Dow JM, Newman MA: Lipopolysaccharides and plant innate immunity. Subcell Biochem 2010, 53:387-403.

59. Xiao PP, Hu YH, Sun L: Scophthalmus maximus cystatin B enhances head kidney macrophage-mediated bacterial killing. Dev Comp Immunol 2010, 34:1237-1241.

60. Koeberle A, Northoff H, Werz O: Identification of 5-lipoxygenase and microsomal prostaglandin E2 synthase-1 as functional targets of the anti-inflammatory and anti-carcinogenic garcinol. Biochem Pharmacol 2009, 77:1513-1521.

61. Dantan-Gonzalez E, Rosenstein Y, Quinto C, Sanchez F: Actin monoubiquitylation is induced in plants in response to pathogens and symbionts. Mol Plant-Microbe Interact 2001, 14:1267-1273.

62. Duperthuy M, Schmitt P, Garzón E, Caro A, Rosa RD, Le Roux F, LautrédouAudouy N, Got P, Romestand B, de Lorgeril J, Kieffer-Jaquinod S, Bachère E, Destoumieux-Garzón D: Use of OmpU porins for attachment and invasion of Crassostrea gigas immune cells by the oyster pathogen Vibrio splendidus. Proc Natl Acad Sci USA 2011, 108:2993-2998.

63. Kimbell JR, McFall-Ngai MJ: Symbiont-induced changes in host actin during the onset of a beneficial animal-bacterial association. App/ Environ Microbiol 2004, 70:1434-1441.

64. Takemoto D, Hardham AR: The cytoskeleton as a regulator and target of biotic interactions in plants. Plant Physiol 2004, 136:3864-3876.
65. DeSalvo MK, Sunagawa S, Fisher PL, Voolstra CR, Iglesias-Prieto R, Medina M: Coral host transcriptomic states are correlated with Symbiodinium genotypes. Mol Ecol 2010, 19:1174-1186.

66. Schwarz JA, Brokstein PB, Voolstra C, Terry AY, Manohar CF, Miller DJ, Szmant AM, Coffroth MA, Medina M: Coral life history and symbiosis: functional genomic resources for two reef building Caribbean corals, Acropora palmata and Montastraea faveolata. BMC Genomics 2008, 9:97.

67. Kremer N, Voronin D, Charif D, Mavingui P, Mollereau B, Vavre F: Wolbachia interferes with ferritin expression and iron metabolism in insects. PLOS Pathog 2009, 5:e1000630.

68. De Cian MC, Andersen AC, Bailly X, Lallier FH: Expression and localization of carbonic anhydrase and ATPases in the symbiotic tubeworm Riftia pachyptila. J Exp Biol 2003, 206:399-409.

69. De Cian MC, Bailly X, Morales J, Strub JM, Van Dorsselaer A, Lallier FH: Characterization of carbonic anhydrases from Riftia pachyptila, a symbiotic invertebrate from deep-sea hydrothermal vents. Proteins 2003, 51:327-339.

70. Sanchez S, Andersen AC, Hourdez S, Lallier FH: Identification, sequencing, and localization of a new carbonic anhydrase transcript from the hydrothermal vent tubeworm Riftia pachyptila. FEBS J 2007, 274:5311-5324.

71. Sarrazin J, Sarradin PM, the MoMARETO cruise participants, Allais AG, Almeida D, Bernagout S, Bettencourt R, Bonnivard E, Brandou V, Briand P, Bruneaux M, Buffier E, Burnet JB, Byrne N, Cardigos F, Coiras E, Cosson RP, Cottin D, Cuvelier D, Dentrecolas S, Desbruyères D, Dorval P, Dupont J, Fabri MC, Gavaia P, Godfroy A, Gouillou M, Gronemann J, Hamel G, Hamon M, Higuet D, et al: MoMARETO: a cruise dedicated to the spatiotemporal dynamics and the adaptations of hydrothermal vent fauna on the Mid-Atlantic Ridge. InterRidge News 2006, 15:24-33.

72. Holm S: A simple sequentially rejective multiple test procedure. Scand $J$ Stat 1979, 6:65-70.

73. Ewing B, Green P: Basecalling of automated sequencer traces using phred. II. Error probabilities. Genome Res 1998, 8:186-194.

74. Ewing B, Hillier L, Wendl M, Green P: Basecalling of automated sequencer traces using phred. I. Accuracy assessment. Genome Res 1998, 8:175-185.

75. Pertea G, Huang X, Liang F, Antonescu V, Sultana R, Karamycheva S, Lee $Y$, White J, Cheung F, Parvizi B, Tsai J, Quackenbush J: TIGR Gene Indices clustering tools (TGICL): a software system for fast clustering of large EST datasets. Bioinformatics 2003, 19:651-652.

76. Consortium U: The universal protein resource (UniProt). Nucleic Acids Res 2008, 36:D190-195

77. Altschul SF, Madden TL, Schäffer AA, Zhang J, Zhang Z, Miller W, Lipman DJ: Gapped BLAST and PSI-BLAST: a new generation of protein database search programs. Nucleic Acids Res 1997, 25:3389-3402.

78. Gagnière N, Jollivet D, Boutet I, Brélivet $Y$, Busso D, Da Silva C, Gaill F, Higuet D, Hourdez S, Knoops B, Lallier F, Leize-Wagner E, Mary J, Moras D, Perrodou E, Rees JF, Segurens B, Shillito B, Tanguy A, Thierry JC, Weissenbach J, Wincker P, Zal F, Poch O, Lecompte O: Insights into metazoan evolution from Alvinella pompejana cDNAs. BMC Genomics 2010, 11:634.

79. Plewniak F, Bianchetti L, Brelivet $Y$, Carles A, Chalmel F, Lecompte O, Mochel T, Moulinier L, Muller A, Muller J, Prigent V, Ripp R, Thierry JC, Thompson JD, Wicker N, Poch O: PipeAlign: A new toolkit for protein family analysis. Nucleic Acids Res 2003, 31:3829-3832.

80. Ashburner M, Ball CA, Blake JA, Botstein D, Butler H, Cherry JM, Davis AP, Dolinski K, Dwight SS, Eppig JT, Harris MA, Hill DP, Issel-Tarver L, Kasarskis A, Lewis S, Matese JC, Richardson JE, Ringwald M, Rubin GM, Sherlock G: Gene ontology: tool for the unification of biology. The Gene Ontology Consortium. Nat Genet 2000, 25:25-29.

81. Chalmel F, Lardenois A, Thompson JD, Muller J, Sahel JA, Léveillard T, Poch O: GOAnno: GO annotation based on multiple alignment. Bioinformatics 2005, 21:2095-2096.

82. Gentleman RC, Carey VJ, Bates DM, Bolstad B, Dettling M, Dudoit S, Ellis B, Gautier L, Ge Y, Gentry J, Hornik K, Hothorn T, Huber W, lacus S, Irizarry R, Leisch F, Li C, Maechler M, Rossini AJ, Sawitzki G, Smith C, Smyth G, Tierney L, Yang JY, Zhang J: Bioconductor: open software development for computational biology and bioinformatics. Genome Biol 2004, 5:R80.

83. Smyth GK, Michaud J, Scott HS: Use of within-array replicate spots for assessing differential expression in microarray experiments. Bioinformatics 2005, 21:2067-2075. 
84. Ritchie ME, Silver J, Oshlack A, Holmes M, Diyagama D, Holloway A, Smyth GK: A comparison of background correction methods for twocolour microarrays. Bioinformatics 2007, 23:2700-2707.

85. Saeed Al, Sharov V, White J, Li J, Liang W, Bhagabati N, Braisted J, Klapa M, Currier T, Thiagarajan M, Sturn A, Snuffin M, Rezantsev A, Popov D,

Ryltsov A, Kostukovich E, Borisovsky I, Liu Z, Vinsavich A, Trush V,

Quackenbush J: TM4: a free, open-source system for microarray data management and analysis. Biotechniques 2003, 34:374-378.

doi:10.1186/1471-2164-12-530

Cite this article as: Boutet et al: Conjugating effects of symbionts and environmental factors on gene expression in deep-sea hydrothermal vent mussels. BMC Genomics 2011 12:530.

Submit your next manuscript to BioMed Central and take full advantage of:

- Convenient online submission

- Thorough peer review

- No space constraints or color figure charges

- Immediate publication on acceptance

- Inclusion in PubMed, CAS, Scopus and Google Scholar

- Research which is freely available for redistribution

Submit your manuscript at www.biomedcentral.com/submit
() Biomed Central 